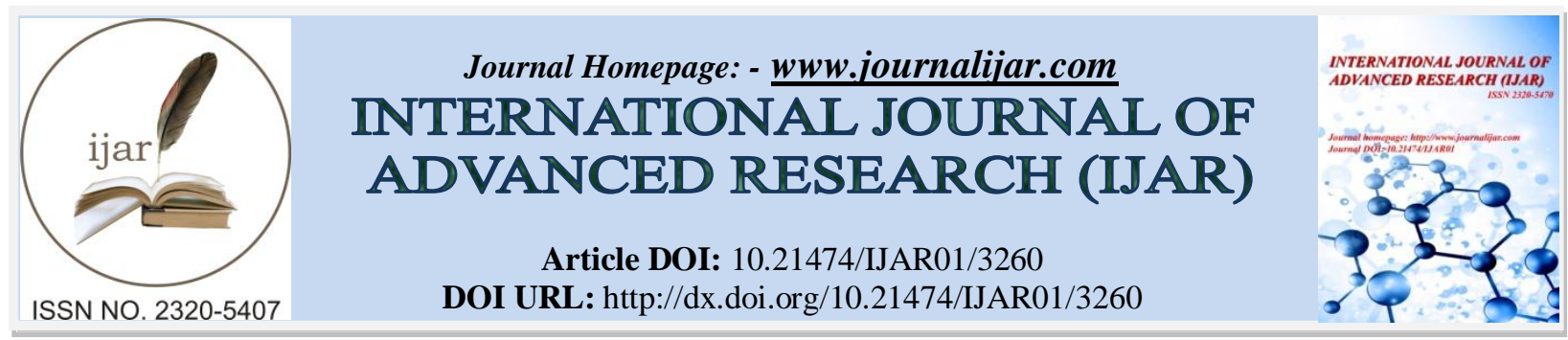

RESEARCH ARTICLE

\title{
A CASE STUDY ON SOLITARY RECTAL ULCER SYNDROME TREATED WITH ERANDAMULADI BASTI FOLLOWED BY GUDAPICHU WITH JATYADI TAILAM.
}

Vd. Deepali Sherekar.

Assistant Professor Dept.of Panchakarma, G.A.C. Nanded MUHS Nashik Maharashtra, india.

\section{Manuscript Info}

Manuscript History

Received: 28 December 2016

Final Accepted: 29 January 2017

Published: February 2017

Key words:-

Solitary Rectal Ulcer Syndrome,

Erandamuladi Basti, Jatyadi tailam,

Gudapichu

\section{Abstract}

Solitary Rectal Ulcer Syndrome is most common in young adults and occurs on the anterior rectal wall. It is thought to result from localized chronic trauma or ischaemia associated with disordered puborectalis function and mucosal prolapse. Symptoms include minor bleeding, mucus per rectum, tenesmus, perianal pain with severe constipation. A 42 years old male patient who presented with complaints of severe constipation, shirashoola, perianal pain, H/o - minor bleeding per rectum only once and colonoscopy shows the impression as Solitary Rectal Ulcer Syndrome. Considering the vitiation of Apana vata, patient was treated with snehana, swedana, Erandamuladi Basti and Gudapichu with Jatyadi taila. This management showed significant result in the above case study, such as relief in parianal pain, straining at defecation, passage of mucus per rectum, bleeding per rectum as well as Healing of an Ulcer in colonoscopy after treatment.

Copy Right, IJAR, 2017,. All rights reserved.

\section{Introduction:-}

Solitary Rectal Ulcer Syndrome is the most common in young adults and occurs on the anterior rectal wall. It is throughout to result from localized chronic trauma or ischaemia associated with disordered puborectalis function and mucosal prolapse.

The ulcer is seen at colonoscopy and biopsies show a characteristic accumulation of collegen. Symptoms include minor bleeding, mucus per rectum, tenesmus, perianal pain and severe constipation. Treatment is often difficult but avoidance of straining at defecation is very important and treatment of constipation may help or else surgical intervention is the next line of treatment for this condition ${ }^{1}$

The symptomatology of patient suggestive of vitiation of Apana vata due to Purishvaha strotodusthi. In first stage patient was C/o severe constipation(Purishasanga), abdominal distension (Adhamana). Sometimes abdominal pain (Pakwashaya shoola) due to H/o Suppression of natural urges i.e. Vegavarodha ${ }^{2}$. Which in turn leads to severe constipation, perianal pain, mucous per rectum, minor bleeding per rectum etc. and showed the impression as colonoscopy revealed a solitary rectal ulcer syndrome.

Considering Purishavaha Sroto dushti, vitiation of Apana vata and Vegavarodha as main causation, this condition can be correlated with Purisha vegavarodhajanya Udavarta leading to Gudagata vrana. ${ }^{3}$ Acharya Sushruta stated the symptoms of Purisha vegavardhajanya udavarta as Abdominal distension (Adhamana and atopa); severe constipation (Purisha sanga), Perianal pain (Parikartana), Belchings (Urdhwa vata) etc. which may lead to local 
ulcer formation due to chronic traumatic injury due to severe constipation. ${ }^{4}$ Acharya Sushruta stated the treatment of Udavarta with Vata predominance is snehana, swedana and Asthapan Basti. ${ }^{5}$

Erandamuladi Basti was selected for this case which is indicated in Purisha and Vayu graham. ${ }^{[6][7]}$ and wound healing procedures described by Sushruta still holds its place today. The faster the wound healing, the faster is the recovery of the patient enabling him to resume his daily routine. So for local application (ropana) Jatyadi taila was selected for Guda-pichu as Guda-gata vrana comes under Sukharopaniya Vrana ${ }^{8}$

\section{Case Report:-}

A 42 years old male patient came Panchakarma OPD of Government Ayurved College, Nanded, Maharashtra, India presented with the complaint of an ulcer on anterior rectal wall associated with severe constipation, perianal pain, mucus per rectum, Sometimes abdominal distension, Pain in calf muscles (Pindikodweshtanam) and H/o minor bleeding per rectum once only -3 months back.

Before one year patient was alright then, later on he was suffering with severe constipation (Purishasanga), belchings(urdhva vata), abdominal pain (Pakwashaya shoola), Head ache (shirashoola) etc. due to H/o Suppression of urges as past history of medical illness.

After medication, some symptoms were relieved. But since 4 months again patient was suffering with the same symptoms.

\section{On examination:-}

General condition - moderate, afebrile

Pulse rate $-70 / \mathrm{min}$, Regular

$\mathrm{BP}-100 / 70 \mathrm{mmHg}$

No H/o HTN/DM/Any major illness/Surgery.

$\mathrm{H} / \mathrm{o}$ - Suppression of urges due to workload,

H/o - occasionally drinking .

Family H/o Nothing specific.

\section{Investigation:-}

Routine haematalogy - (Hb, TC, DC, ESR, RBS, Platelet count) and urine investigations were done and were within normal limits.

\section{Colonoscopy:-}

Rectum:- Small superficial ulcer with few erosions.

Impressions:- Solitary rectal ulcer syndrome

Biopsy report:- Non specific mild chronic inflammation. No definitive feature of Solitary Rectal Ulcer Syndrome seen given biopsy.

Patient had received treatment for it but there was no relief in symptoms so came to Ayurvedic hospital for the needful.

As Sushruta has described the treatment for Purishavegavarodhajanya Udavarta and guda-gata vrana is Snehana, Swedana, Asthapana basti and for guda-gata vrana - ropana was planned.

\section{Treatment Given:-}

Patient was treated with Snehana, swedana, and Erandamuladi Nruha Basti and Guda-pichu with Jatyadi taila.

\begin{tabular}{|c|c|c|c|}
\hline Procedure & Medication & Dose & Duration. \\
\hline Sarvanga abhyanga & & approx $60 \mathrm{ml}$ & $\begin{array}{l}25-30 \mathrm{~min} \text { per day } 8 \text { days } \\
10-15 \mathrm{~min} / \text { day for } 8 \text { days }\end{array}$ \\
\hline Nadi swedana & Dashamooola Kwatha & - & Twice daily for 8 days \\
\hline Guda-pichu & Jatyadi taila & 3 to $5 \mathrm{ml}$. & \\
\hline Pradhan Karma Yoga Basti & $\begin{array}{l}\text { Anavasan with Prasarini taila } \\
\text { Asthapana with Erandamuladi basti }\end{array}$ & $\begin{array}{l}80 \mathrm{ml} \\
\text { Approx } 480 \mathrm{ml}\end{array}$ & $\begin{array}{l}\text { Start with Anvasana } \\
\text { Alternate day } \\
8 \text { days }\end{array}$ \\
\hline
\end{tabular}


Ingredients of Erandamuladi Basti.

\begin{tabular}{|c|c|c|}
\hline & Drug & Quantity \\
\hline Honey & Makshika & $20 \mathrm{gm}$ \\
\hline Rocksalt & Lavana & $10 \mathrm{gm}$ \\
\hline Sahachara taila & Sneha & $100 \mathrm{ml}$ \\
\hline Yastimadhu & Kalka & $30 \mathrm{gm}$ \\
\hline Erandamujladi & Kwatha & $320 \mathrm{ml}$ \\
\hline
\end{tabular}

Anuvasan with -> Prasarini taila $-80 \mathrm{ml}$ daily

Niruha - > Kalka -> yasthimadhu $-30 \mathrm{mg}$

Kwatha $\rightarrow \quad$ Erandamoola -3 parts + Palasha + Laghupanchamoola + Rasna +

Aswagandha + Atibala + Guduchi + Punarnava + Araogawadha + Devadaru - each 1 part \& Madanphala - 1 part.

Preparation:- The process for preparation was followed as described by Sharangadhara in Hina matra.

\section{Asssesment Criteria:-}

1) Perianal pain

(Parikartanam)

2) Constipation

(Purisha sanga)

3) Headache

(Shirashoola)

4)

Abdominal distension

(Pindikodweshtanam)

0 - $\quad$ Absent

1 - $\quad$ Mild

- $\quad$ Moderate

3 - $\quad$ Severe

0 - Absent

$0 \quad-\quad$ Absent

2 - $\quad$ Moderate

$\begin{array}{lll}2 & - & \end{array}$

0 - $\quad$ Absent

1 - $\quad$ Mild

2 - $\quad$ Moderate

3 - $\quad$ Severe

$\begin{array}{lll}- & \text { Absent } \\ 1 & - & \text { Mild }\end{array}$

$\begin{array}{lll}3 & - & \text { Severe }\end{array}$

5) Pain in Calf Muscles $0 \quad$ - $\quad$ Absent

(Adhaman) $\quad 1 \quad$ - $\quad$ Mild

6) 3 - $\quad$ Severe

6) Mucous per rectum $0 \quad$ - $\quad$ Absent

$1 \quad-\quad$ Mild

$\begin{array}{lll}2 & - & \text { Moderate } \\ 3 & - & \text { Severe }\end{array}$

\begin{tabular}{|c|c|c|}
\hline Signs and symptoms & BT & AT \\
\hline 1. Periamal Pain & 2 & 0 \\
\hline 2. Constipation & 3 & 0 \\
\hline 3. Headache & 2 & 0 \\
\hline 4. Abdominal distension & 1 & 1 \\
\hline 5. Pain in calf muscles & 3 & 0 \\
\hline 6. Mucous per rectum & 1 & Healing rectal ulcer \\
\hline Colonoscopy & Solitary ulcer syndrome & . \\
\hline
\end{tabular}

\section{Discussion:-}

The symptomatology of Solitary Rectal Ulcer Syndrome denotes the apana vayu dushti due to vegavarodhajanya hetu, again leads to vata prakopa. Severe constipation leads to trauma producing the ulceration at superficial rectal wall. 
Basti is the main line of treatment for vataprakopa and Erandamuladi Basti helps in malnirharana and vatunolamana.

Madhu is vranaropaka and used as catalyst. The fatty acids present in honey stimulates peristalsis.

Saindhava due to its sukshma and tikshna property helps the basti dravya to reach up to microcellular level.

$>$ Yashtimadhu helps for vatanulomana and acts as vranaropana.

$>$ Eranda is Kaphavatahara acts as rechana and shoolahara. Palasha as deepana and bhedana, Laghupanchamoola as shothahara and Rasna as amapachana and shoolhara.

Prasarini taila is Kaphavatahara and does vatanulomana. Punarnava is shothhara Ashwagandha as Balya, rasayana, Atibala as balya and brumhana, Argawadha as rechana and Madanaphala and Devdaru as vatanulomana helps Erandamuladi basti to reduce strotorodha.

Prasarini taila also kaphavatahara and does vatanulomana.

So in this case study, patient got relief in perianal pain, constipation, headache, abdominal distension, mucous per rectum and healing of an ulcer was reported in colonoscopy after completion of treatment.

\section{Conclusion:-}

Basti acts through systemic correction and regulation of doshas which involves in the formation i.e. Apana vata dushti in solitary rectal ulcer syndrome.

Erandamuladi Niruha Basti showed very good result in reducing the symptoms as well as in healing the ulcer.

From the above study, it can be said that Erandamuladi Basti and ropana with Jatyadi taila might prove beneficial to the patients with Severe constipation leading to Solitary rectal ulcer syndrome.

It was an attempt made to provide safe and effective management with least expenditure.

\section{References:-}

1. Christopher Haslett, Edwin R. Chilvers, John A.A.Hunter, Nicholas A, Boon 2008 edition, Davidson's Principles and practice of Medicine, 2006 P.No. 680.

2. Vaidya Yadavji Trikamji, acharya, Sushruta Samhita with Dalhanacharya Nibandha Sangraha and Gayadasacharya Nyaychandrka Panjika Commentary edited by Krishnadas Academy, Varanasi, Edition reprint in 1998 -Uttartantra $55^{\text {th }}$ chapter / 4 P. No. 404

3. Vaidya Yadavji Trikamji, acharya, Sushruta Samhita with Dalhanacharya Nibandha Sangraha and Gayadasacharya Nyaychandrka Panjika Commentary edited by Krishnadas Academy, Varanasi, Edition reprint in 1998 -Uttartantra $55^{\text {th }}$ chapter / 4 P. No. 405

4. Yadavji Trikamji, editor Ayurved dipika, Sanskrit commentary, Charak samhita, Chaukhamba Prakashana, 2013.

5. Vaidya Yadavji Trikamji, acharya, Sushruta Samhita with Dalhanacharya Nibandha Sangraha and Gayadasacharya Nyaychandrka Panjika Commentary edited by Krishnadas Academy, Varanasi, Edition reprint in 1998 -Uttartantra $55^{\text {th }}$ chapter / 19-20 P. No. 408.

6. Yadavji Trikamji, editor Ayurved dipika, Sanskrit commentary, Charak samhita, Chaukhamba Prakashana, 2013. Ch.viman sthana $3 / 8$

7. Vaidya Harish Shastri Paradkar, Editor-Ashtangahridaya, Sarvangasundara of Arun Datta Ashtanga Kalpasthana 4/710

8. Vaidya Yadavji Trikamji, acharya, Sushruta Samhita with Dalhanacharya Nibandha Sangraha and Gayadasacharya Nyaychandrka Panjika Commentary edited by Krishnadas Academy, Varanasi, Edition reprint in 1998 - Sutrasthana chapter / 21/6 P. No. 87 